\title{
N-Terminal Fatty Acylation of Transducin Profoundly Influences Its Localization and the Kinetics of Photoresponse in Rods
}

\author{
Vasily Kerov, ${ }^{1}$ William W. Rubin, ${ }^{2}$ Michael Natochin, ${ }^{1}$ Nathan A. Melling, ${ }^{2}$ Marie E. Burns, ${ }^{2}$ and Nikolai 0. Artemyev ${ }^{1}$ \\ ${ }^{1}$ Department of Molecular Physiology and Biophysics, University of Iowa College of Medicine, Iowa City, Iowa 52242 , and ${ }^{2}$ Center for Neuroscience and \\ Department of Psychiatry and Behavioral Sciences, University of California, Davis, Davis, California 95616
}

\begin{abstract}
$\mathrm{N}$-terminal acylation of the $\alpha$-subunits of heterotrimeric G-proteins is believed to play a major role in regulating the cellular localization and signaling of G-proteins, but physiological evidence has been lacking. To examine the functional significance of $\mathrm{N}$-acylation of a well understood G-protein $\alpha$-subunit, transducin $\left(\mathrm{G} \alpha_{\mathrm{t}}\right)$, we generated transgenic mice that expressed a mutant $\mathrm{G} \alpha_{\mathrm{t}}$ lacking $\mathrm{N}$-terminal acylation sequence $\left(\mathrm{G} \alpha_{\mathrm{t}} \mathrm{G} 2 \mathrm{~A}\right)$. Rods expressing $\mathrm{G} \alpha_{\mathrm{t}} \mathrm{G} 2 \mathrm{~A}$ showed a severe defect in transducin cellular localization. In contrast to native $\mathrm{G} \alpha_{\mathrm{t}}$, which resides in the outer segments of dark-adapted rods, $\mathrm{G} \alpha_{\mathrm{t}} \mathrm{G} 2 \mathrm{~A}$ was found predominantly in the inner compartments of the photoreceptor cells. Remarkably, transgenic rods with the outer segments containing $\mathrm{G} \alpha_{\mathrm{t}} \mathrm{G} 2 \mathrm{~A}$ at $5-6 \%$ of the $\mathrm{G} \alpha_{\mathrm{t}}$ levels in wild-type rods showed only a sixfold reduction in sensitivity and a threefold decrease in the amplification constant. The much smaller than predicted reduction may reflect an increase in the lateral diffusion of transducin and an increased activation rate by photoexcited rhodopsin or more efficient activation of cGMP phosphodiesterase 6 by G $\alpha_{t} \mathrm{G} 2 \mathrm{~A}$; alternatively, nonlinear relationships between concentration and the activation rate of transducin also potentially contribute to the mismatch between the amplification constant and quantitative expression analysis of $\mathrm{G} \alpha_{\mathrm{t}} \mathrm{G} 2 \mathrm{~A}$ rods. Furthermore, the G2A mutation reduced the GTPase activity of transducin and resulted in two to three times slower than normal recovery of flash responses of transgenic rods, indicating the role of $G \alpha_{t}$ membrane tethering for its efficient inactivation by the regulator of G-protein signaling 9 GTPase-activating protein complex. Thus, $\mathrm{N}$-acylation is critical for correct compartmentalization of transducin and controls the rate of its deactivation.
\end{abstract}

Key words: phototransduction; retina; transducin; N-acylation; G-proteins; vision

\section{Introduction}

Heterotrimeric G-proteins mediate the transduction of a variety of extracellular signals that activate G-protein-coupled receptors at the plasma membrane (Bourne, 1997; Pierce et al., 2002; Cabrera-Vera et al., 2003). The vertebrate rod phototransduction cascade represents one of the best model systems to study the mechanisms of G-protein signaling. Rod transducin $\left(G_{t}\right)$ couples photoexcitation of rhodopsin (R) to the activation of cGMP phosphodiesterase 6 (PDE6). The GTP-bound $\alpha$-subunit of $\mathrm{G}_{\mathrm{t}}$ ( $\mathrm{G} \alpha_{\mathrm{t}} \mathrm{GTP}$ ) binds to the $\gamma$-subunit of PDE6 (P $\gamma$ ), activating the enzyme. The $\mathrm{G} \alpha_{\mathrm{t}} \mathrm{GTP} / \mathrm{PDE} 6$ complex is deactivated when bound GTP is hydrolyzed as a result of intrinsic GTPase activity of $\mathrm{G} \alpha_{\mathrm{t}}$ controlled by the GTPase-activating protein (GAP) complex, regulator of G-protein signaling 9-1 (RGS9-1)/G $\beta_{5} / \mathrm{RGS9}$ anchor protein (R9AP) (Burns and Baylor, 2001; Burns and Arshavsky, 2005).

\footnotetext{
Received June 1, 2007; revised July 31, 2007; accepted July 31, 2007.

This work was supported by National Institutes of Health Grants R01 EY-12682 (N.0.A.) and EY14047 (M.E.B.). We thank Dr. Edward N. Pugh Jr for critical reading of this manuscript and valuable comments.

Correspondence should be addressed to Nikolai 0 . Artemyev, Department of Molecular Physiology and Biophysics, University of lowa College of Medicine, 5-532 Bowen Science Building, lowa City, IA 52242. E-mail: nikolai-artemyev@uiowa.edu.

DOI:10.1523/JNEUROSCI.2494-07.2007

Copyright $\odot 2007$ Society for Neuroscience $\quad$ 0270-6474/07/2710270-08\$15.00/0
}

Lipid modifications of G-proteins are thought to play a major role in the regulation of G-protein cellular localization and signaling (Wedegaertner et al., 1995; Higgins and Casey, 1996; Chen and Manning, 2001). Most G-protein $\gamma$-subunits (G $\gamma$ s) are modified with a thioether-linked isoprenoid geranylgeranyl (C20) attached to Cys residues within the C-terminal "CAAX" box (Escriba et al., 2006). In contrast, the rod-specific $\mathrm{G} \gamma_{1}$ carries the farnesyl moiety (C15), which facilitates light-dependent translocation of $G_{t}$ from the rod outer segment (ROS) to the inner compartments, thereby contributing to light adaptation (Kassai et al., 2005). G $\alpha$-subunits are typically modified with an amidelinked fatty acid myristate (C14:0) at the extreme N-terminal Gly residue and/or with a thioester-linked palmitate (C16:0) at Cys residues near the $\mathrm{N}$ termini (Wedegaertner et al., 1995; Chen and Manning, 2001). Uniquely, $\operatorname{rod} \mathrm{G} \alpha_{\mathrm{t}}$ is heterogeneously fatty N-acylated with C12:0, C14:0, C14:1, and C14:2 moieties (Neubert et al., 1992). The lower hydrophobicity of the $\mathrm{G} \alpha_{\mathrm{t}}$ acyl residues also assists light-dependent redistribution of transducin between the outer segment (OS) and inner regions of rods (Lobanova et al., 2007).

Although the heterogeneity of $\mathrm{G} \alpha_{\mathrm{t}}$ lipid modification may influence certain aspects of phototransduction and light adaptation (Neubert and Hurley, 1998; Lobanova et al., 2007), the significance of the lipid modification itself is expected to be much 
A

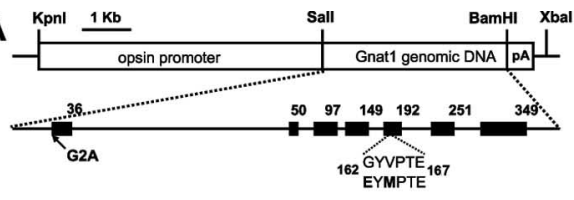

B WT $\quad$ G2A/G $\alpha_{t}^{+1-} \mid G 2 A / G \alpha_{t}^{-l-}$

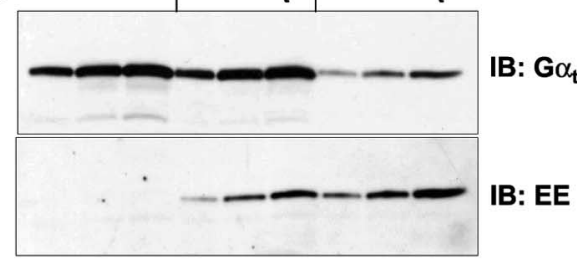

$\begin{array}{llllllllll}10 & 15 & 22.5 & 10 & 15 & 22.5 & 10 & 15 & 22.5 & \mu \mathrm{g} \text { ret. pr. }\end{array}$

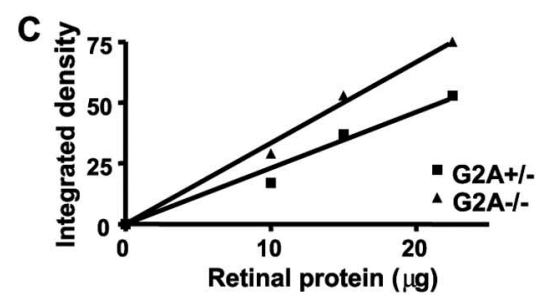

Figure 1. $\boldsymbol{A}$, Transgenic construct used for the generation of mutant $\mathrm{G} \alpha_{\mathrm{t}} \mathrm{G} 2 \mathrm{~A}$ mice. $\boldsymbol{B}$, Expression levels of $\mathrm{G} 2 \mathrm{~A}$ mutant in $\mathrm{G} \alpha_{\mathrm{t}} \mathrm{G} 2 \mathrm{~A} / \mathrm{G} \alpha_{\mathrm{t}}{ }^{+/-}$and $\mathrm{G} \alpha_{\mathrm{t}} \mathrm{G} 2 \mathrm{~A} / \mathrm{G} \alpha_{\mathrm{t}}{ }^{-/-}$mice. Retinas from transgenic and control $\left(\mathrm{G} \alpha_{\mathrm{t}}{ }^{+/+}\right)$mice were homogenized and subjected to SDS-PAGE. Sample loads are in micrograms of retinal protein (ret. pr.). Immunoblot (IB) analysis was performed with anti-rod $G \alpha_{t}$ and anti-EE antibodies. $\boldsymbol{C}$, Quantification of protein levels from the anti-EE antibody immunoblot in $\boldsymbol{B}$. The relative level of $\mathrm{G} \alpha_{\mathrm{t}} \mathrm{G} 2 \mathrm{~A}$ in $\mathrm{G} \alpha_{\mathrm{t}} \mathrm{G} 2 \mathrm{~A} / \mathrm{G} \alpha_{\mathrm{t}}{ }^{-1-}$ mice is 1.5 -fold higher than in $\mathrm{G} \alpha_{\mathrm{t}} \mathrm{G} 2 \mathrm{~A} / \mathrm{G} \alpha_{\mathrm{t}}{ }^{+/-}$mice (calculated as the ratio of the linear fit slopes). $\boldsymbol{D}$, Immunoblot analyses of key phototransduction proteins. Samples contained $2.5,5$, and $10 \mu \mathrm{g}$ of retinal homogenate from 4-month-old $\mathrm{G} \alpha_{\mathrm{t}} \mathrm{G} 2 \mathrm{~A} / \mathrm{G} \alpha_{\mathrm{t}}{ }^{-/-}$or control WT mice. The antibodies are described in Materials and Methods. E, Quantification of the relative protein levels from the immunoblot in $\boldsymbol{D}$. Integrated densities for each protein band were plotted as a function of retinal homogenate load to determine the linear fit slopes and the ratios of the slopes for WT and mutant mice. Arr, Arrestin.

more profound. The $\mathrm{N}$-terminal acylation may be required for proper transport and localization of transducin to the OS. On the disc membrane, the $\mathrm{G} \alpha_{\mathrm{t}}$ lipid anchor may control the lateral diffusion and collisional coupling of $\mathrm{G} \alpha_{\mathrm{t}}$ with photoexcited rhodopsin $\left(\mathrm{R}^{\star}\right)$. Furthermore, the $\mathrm{G} \alpha_{\mathrm{t}}$ lipid is potentially critical for PDE6 acti-vation and inactivation. The activated $\mathrm{G} \alpha_{\mathrm{t}} \mathrm{GTP} / \mathrm{PDE} 6$ complex is membrane bound and stabilized by the $\mathrm{G} \alpha_{\mathrm{t}}$ and PDE6 lipid modifications (Catty et al., 1992; Clerc and Bennett, 1992). The ability of the GAP complex to rapidly inactivate the $\mathrm{G} \alpha_{\mathrm{t}} \mathrm{GTP} / \mathrm{PDE} 6$ complex depends on the membrane attachment of the GAP complex via the anchor protein, R9AP (Lishko et al., 2002, Hu et al., 2003).

Despite growing data supporting the roles of $\mathrm{N}$-acylation of $\mathrm{G} \alpha$ subunits for localization and transduction efficiency of G-proteins, functional evidence for the importance in cell signaling is lacking. To probe the functional significance of the $\mathrm{N}$-acylation of $\mathrm{G} \alpha_{\mathrm{t}}$ in intact cells, we have produced and examined transgenic mice expressing an acylation-deficient mutant, $\mathrm{G} \alpha_{\mathrm{t}} \mathrm{G} 2 \mathrm{~A}$, in rod photoreceptors.

\section{Materials and Methods}

Generation of $G \alpha_{t} G 2 A$ transgenic mice. A pBRH $G \alpha_{\mathrm{t}}$ transgenic construct contained the mouse $\mathrm{G} \alpha_{\mathrm{t}}$ genomic sequence of $\sim 5.5 \mathrm{~kb}$ (Raport et al., 1989) flanked by the $4.4 \mathrm{~kb}$ mouse rod opsin promoter fragment (Lem et al., 1991) and polyadenylation signal (Fig. 1A). The transgene sequence was mutated previously to introduce the Glu-Glu (EE) monoclonal antibody epitope to assess expression levels of mutant transducins in mouse retinas (Kerov et al., 2005; Moussaif et al., 2006). The G2A substitution was created using the QuickChange mutagenesis kit (Stratagene, La Jolla, CA). A DNA fragment of $9 \mathrm{~kb}$ was released from the $\mathrm{pBRH}-\mathrm{G} \alpha_{\mathrm{t}} \mathrm{EEG} 2 \mathrm{~A}$ plasmid by restriction with NotI and gel purified. The DNA fragment was microinjected into mouse embryos at the transgenic core facility at the University of Iowa. Transgenic mice were identified by PCR of mouse tail DNA with a pair of primers chosen to amplify a $300 \mathrm{bp}$ fragment surrounding the junction between the $\mathrm{G} \alpha_{\mathrm{t}}$ and polyadenylation signal sequences. Six potential $\mathrm{G} \alpha_{\mathrm{t}} \mathrm{G} 2 \mathrm{~A}$ transgenic mouse founders were identified and mated to C57BL/6 mice. The founder line with the highest expression level of $\mathrm{G} \alpha_{\mathrm{t}} \mathrm{G} 2 \mathrm{~A}$ was selected for breeding with $\mathrm{G} \alpha_{\mathrm{t}}$ knock-out mice $\left(\mathrm{G}_{\mathrm{t}}{ }^{-/-}\right)$to produce $\mathrm{G} \alpha_{\mathrm{t}} \mathrm{G} 2 \mathrm{~A} / \mathrm{G} \alpha_{\mathrm{t}}{ }^{+/-}$ transgenic mice hemizygous for native $\mathrm{G} \alpha_{\mathrm{t}}$ allele. $\mathrm{G} \alpha_{\mathrm{t}} \mathrm{G} 2 \mathrm{~A} / \mathrm{G} \alpha_{\mathrm{t}}{ }^{+/-}$mice were further mated with $\mathrm{G} \alpha_{\mathrm{t}}{ }^{-1-}$ mice to move the transgene into the knock-out $\left(\mathrm{G}_{\mathrm{t}}{ }^{-1-}\right)$ background. $\mathrm{G} \alpha_{\mathrm{t}} \mathrm{G} 2 \mathrm{~A} / \mathrm{G} \alpha_{\mathrm{t}}{ }^{-1-}$ mice were identified by the absence of $\mathrm{PCR}$ product using primers designed to amplify a DNA sequence only from the wildtype $\mathrm{G} \alpha_{\mathrm{t}}$ allele. All experimental procedures involving the use of mice were performed in accordance with the National Institutes of Health (NIH) guidelines and the protocol approved by the University of Iowa Animal Care and Use Committee.

Immunoblot analysis and quantification of transgene expression. Total mouse retinal homogenates were obtained by solubilization of two retinas in $100 \mu \mathrm{l}$ of $10 \%$ SDS-Na using brief sonication. Protein concentrations were determined using the DC protein assay (Bio-Rad, Hercules, CA) and bovine serum albumin dissolved in $10 \%$ SDS-Na as the standard. Typically, the total protein content of a homogenate obtained from a single mouse retina was $\sim 500$ $\mu \mathrm{g}$. Samples of retinal homogenates were subjected to SDS-PAGE in $12 \%$ gels, transferred onto nitrocellulose membranes BA 85 (Schleicher and Schuell, Keene, $\mathrm{NH}$ ), and probed with the following primary antibodies (1:1000 dilution): anti-rod $\mathrm{G} \alpha_{\mathrm{t}}(\mathrm{K}-20)$, anti-G $\beta_{1}(\mathrm{M}-14)$, and anti-G $\gamma_{1}(\mathrm{P}-19)$ (Santa Cruz Biotechnology, Santa Cruz, CA); EE monoclonal (Covance, Princeton, NJ); monoclonal anti-rhodopsin 1D4 (National Cell Culture Center, Minneapolis, MN); anti-PDE6 $\alpha \beta$ MOE antibodies (Cytosignal, Irvine, $\mathrm{CA}$ ); anti-arrestin (PA1-731; ABR, Golden, CO), and anti-RGS9 antibodies (Elmira Biologicals, Iowa City, IA). According to the manufacturer, the epitope of anti-rod $\mathrm{G} \alpha_{\mathrm{t}}$ antibody K-20 is located within residues $80-120$ of human $\mathrm{G} \alpha_{\mathrm{t}}$. Thus, the affinity of this antibody for $\mathrm{G} \alpha_{\mathrm{t}}$ should not be affected by the G2A or EE mutations. The antibody-antigen complexes were detected using secondary anti-rabbit, anti-mouse, or anti-sheep antibodies $(1: 10,000)$ conjugated to horseradish peroxidase (Santa Cruz Biotechnology) and ECL reagent (GE Healthcare, Piscataway, NJ). Nitrocellulose membranes were exposed to film, and integrated densities of scanned individual bands were measured with Image J 1.33 u software.

Immunohistochemistry. For dark adaptation, mice were kept in the dark for at least $12 \mathrm{~h}$. All dark procedures were performed under infrared illumination using night vision goggles. Eyeballs were enucleated, and the corneas were perforated with a 21 gauge needle, fixed in PBS with 4\% formaldehyde for $1 \mathrm{~h}$, and cut in half. The cornea and lens were removed, and the eyecups were submersed in a 30\% sucrose solution in PBS for $5 \mathrm{~h}$ at $4^{\circ} \mathrm{C}$. The eyecups were then embedded in tissue freezing medium (Triangle Biomedical Sciences, Durham, NC) and frozen on dry ice. Radial sectioning $(10 \mu \mathrm{m})$ of the retina was performed using a cryomicrotome HM 505E. Retinal cryosections were air dried and kept at $-80^{\circ} \mathrm{C}$. The sections were warmed up to room temperature and incubated in PBS/0.1\% Triton X-100 for 30 min. Next, $2 \%$ goat serum and 5\% BSA in PBS was added, and incubation continued for $30 \mathrm{~min}$. Sections were then incubated with rabbit anti-rod $\mathrm{G} \alpha_{\mathrm{t}}$ antibody (K-20; 1:2000; Santa Cruz 
Biotechnology) and a monoclonal anti-EE antibody (1:2000; Covance) for $3 \mathrm{~h}$. After a $1 \mathrm{~h}$ incubation with goat anti-rabbit AlexaFluor 555 or goat anti-mouse AlexaFluor 488 secondary antibodies (1:1000; Invitrogen, Carlsbad, CA), the sections were visualized using a Zeiss (Thornwood, NY) LSM 510 confocal microscope. To evaluate mouse retina morphology, eyeballs were fixed in $2.5 \%$ gluteraldehyde in $0.1 \mathrm{M}$ cacodylate buffer for $2 \mathrm{~h}$ at $22^{\circ} \mathrm{C}$, cut in half to remove the cornea and lens, dehydrated through a series of acetones, and embedded in Epon. Radial sections $(1 \mu \mathrm{m})$ were stained with toluidine blue and photographed through a Nikon (Tokyo, Japan) Optiphot microscope using a Spot camera (Diagnostic Instruments, Sterling Heights, MI).

Biochemical analysis of transducin function in mouse ROS membranes. Mouse ROS membranes were prepared using a procedure that allows isolation of osmotically intact and sealed ROS, thereby guarding against loss of OS proteins (Tsang et al., 1998). Rhodopsin concentrations were determined using the difference in absorbance at $500 \mathrm{~nm}$ before and after photobleaching of ROS preparations solubilized in $1 \%$ Ammonix LO. To measure light-dependent binding of GTP $\gamma S$, ROS $(10 \mu \mathrm{l})$ from darkadapted $\mathrm{G} \alpha_{\mathrm{t}} \mathrm{G} 2 \mathrm{~A} / \mathrm{G} \alpha_{\mathrm{t}}{ }^{-1-}$ or control $\mathrm{G} \alpha_{\mathrm{t}}{ }^{+/+}$mice containing $10 \mu \mathrm{M}$ rhodopsin were mixed with $5 \mu \mathrm{l}$ of $10 \mu \mathrm{M}\left[{ }^{35} \mathrm{~S}\right] \mathrm{GTP} \gamma \mathrm{S}$ under infrared illumination. After $10 \mathrm{~s}$ of incubation, the amount of bound GTP $\gamma S$ was determined in a $6 \mu \mathrm{l}$ aliquot by the nitrocellulose filter binding assay. The rest of the sample was bleached to determine the GTP $\gamma \mathrm{S}$ binding in the light.

The single-turnover GTPase measurements were initiated by mixing photobleached ROS $(12 \mu \mathrm{l})$ containing $10 \mu \mathrm{M}$ rhodopsin with $3 \mu \mathrm{l}$ of 0.1 $\mu \mathrm{M}\left[\gamma_{-}{ }^{32} \mathrm{P}\right] \mathrm{GTP}$. The time course of ${ }^{32} \mathrm{P}_{\mathrm{i}}$ formation was determined using the activated charcoal procedure after the reactions were stopped with perchloric acid. The GTPase rate constants were calculated by fitting the experimental data to an exponential function:

$$
\% \text { GTP hydrolyzed }=100\left(1-e^{-k t}\right),
$$

where $k$ is a rate constant for GTP hydrolysis.

To measure PDE6 activation by transducin, photobleached ROS $(3 \mu \mathrm{M}$ R) were incubated with $3 \mu \mathrm{M}$ cGMP for 3 min to stabilize the PDE6 basal activity (Tsang et al., 1998). The reactions were started by the addition of $4 \mathrm{~mm}\left[{ }^{3} \mathrm{H}\right] \mathrm{cGMP}$ with or without $10 \mu \mathrm{M}$ GTP $\gamma \mathrm{S}$. To activate PDE by limited trypsinolysis, ROS samples were incubated with tosyl phenylalanyl chloromethyl ketone-treated trypsin $(50 \mu \mathrm{g} / \mathrm{ml})$ for $4 \mathrm{~min}$ on ice followed by incubation with soybean trypsin inhibitor $(250 \mu \mathrm{g} / \mathrm{ml})$ for 5 min at $25^{\circ} \mathrm{C}$. cGMP hydrolysis was terminated after $30 \mathrm{~s}$ by heating the samples for $2 \mathrm{~min}$ at $100^{\circ} \mathrm{C}$. After cooling, $0.1 \mathrm{U}$ of bacterial alkaline phosphatase (Sigma-Aldrich, St. Louis, MO) was added to each sample followed by incubation for $20 \mathrm{~min}$ at $37^{\circ} \mathrm{C}$. Nonhydrolyzed cGMP was removed with AG1-X2 anion exchange resin (Bio-Rad), and $\left[8-{ }^{3} \mathrm{H}\right]$ guanosine was counted in a liquid scintillation counter.

To assess pertussis toxin-catalyzed G $\beta_{1} \gamma_{1}$-dependent ADP ribosylation of $\mathrm{G} \alpha_{\mathrm{t}}$, dark-isolated or bleached wild-type (WT) ROS (0.6 $\left.\mu \mathrm{M} \mathrm{R}\right)$ and $\mathrm{G} \alpha_{\mathrm{t}} \mathrm{G} 2 \mathrm{~A} / \mathrm{G} \alpha_{\mathrm{t}}{ }^{-1-}$ ROS membranes $(6 \mu \mathrm{M} \mathrm{R})$ were incubated with 3 $\mu \mathrm{g} / \mathrm{ml}$ of pertussis toxin (preactivated by $15 \mathrm{~min}$ incubation at $30^{\circ} \mathrm{C}$ with $100 \mathrm{~mm}$ dithiothreitol and $0.2 \% \mathrm{SDS}$ ) and $5 \mu \mathrm{M}\left[{ }^{32} \mathrm{P}\right]$ nicotinamide adenine dinucleotide $\left(\left[{ }^{32} \mathrm{P}\right] \mathrm{NAD}\right)$ for $1 \mathrm{~h}$ at $25^{\circ} \mathrm{C}$ in the presence or absence of $30 \mu \mathrm{M} \mathrm{AlCl}_{3}$ and $10 \mathrm{~mm} \mathrm{NaF}$. The reactions were stopped by the addition of SDS-sample buffer and analyzed by SDS-PAGE in 12\% gels and autoradiography.

Suction electrode recordings and analysis. Mice were cared for and handled following an approved protocol from the Animal Care and Use Committee of the University of California, Davis and in compliance with $\mathrm{NIH}$ guidelines for the care and use of experimental animals. Before an experiment, animals were dark adapted overnight for a minimum of $12 \mathrm{~h}$. Animals were anesthetized and killed under infrared light, and the retinas were dissected and stored on ice in L-15 solution with $10 \mathrm{~mm}$ glucose and $0.1 \mathrm{mg} / \mathrm{ml}$ bovine serum albumin (Sigma-Aldrich). For recording, a small piece of retina was chopped into small pieces in a chamber containing the L- 15 solution, and the chopped tissue was then placed in a recording chamber perfused with bicarbonate solution, $\mathrm{pH}$ 7.4, supplemented with $10 \mathrm{~mm}$ glucose held at $35-37^{\circ} \mathrm{C}$. Individual rods were visualized under infrared light using a CCD camera (Stanford Photonics,
Palo Alto, CA). The outer segment of an individual rod was gently drawn into the tip of a capillary pipette containing HEPES solution, $\mathrm{pH}$ 7.4. The membrane currents were recorded by a current-to-voltage converter (Axopatch 1B; Molecular Devices, Union City, CA) and low-pass filtered (eight-pole Bessel; Frequency Devices, Haverhill, MA) using $30 \mathrm{~Hz}$ corner frequency. Data were digitized at $200 \mathrm{~Hz}$ using IGOR-National Instruments acquisition software (IgorPro for NIDAQ for Windows; Wavemetrics, Lake Oswego, OR). Rods were presented with $10 \mathrm{~ms}$ flashes of $500 \mathrm{~nm}$ light. The intensity of the light was controlled by using calibrated neutral density filters.

The form of the single-photon response was calculated by squaring the average response to 30 or more dim (linear) responses and scaling it to coincide with the time course of the ensemble light-dependent variance over the initial rising phase. Assuming the predominant source of variance over this time scale arises from Poisson fluctuations in the number of photoexcited rhodopsins, the inverse of this scaling factor corresponds to the average number of photoisomerizations per trial. The average linear response was then divided by the average number of photoisomerizations per trial to yield the average single-photon response. The effective collecting area was calculated by dividing the average number of photoisomerizations per trial by the flash strength (in photons $\cdot \mu \mathrm{m}^{-2}$ ).

The time constant of recovery for dim flash responses was determined by least-squares fitting of a single exponential to the final falling phase of the response; for bright flash responses, a straight line was fitted to the relationship between the time in saturation and the natural log of the flash strength up to $\ln i=9$ (Krispel et al., 2006). The integration time was calculated as the time integral of the dim flash response divided by the peak amplitude.

\section{Results \\ Expression and localization of $\mathrm{G} \alpha_{\mathrm{t}} \mathrm{G} 2 \mathrm{~A}$ mutant in transgenic rods}

The G2A substitution was introduced into a transgene previously used for expression of the monoclonal antibody EE epitopetagged transducin mutant (Fig. 1 A) (Kerov et al., 2005; Moussaif et al., 2006). The EE tag facilitates determination of the expression levels and localization of the $\mathrm{G} \alpha_{\mathrm{t}} \mathrm{G} 2 \mathrm{~A}$ mutant in the presence of native $\mathrm{G} \alpha_{\mathrm{t}}$ in transgenic rods. The EE tag does not alter biochemical properties of transducin, and the flash responses from transgenic mouse rods expressing $\mathrm{G} \alpha_{\mathrm{t}} \mathrm{EE}$ are similar to those from the wild-type rods (Kerov et al., 2005; Moussaif et al., 2006). Several transgenic mouse lines expressing the EE-tagged $\mathrm{G} \alpha_{\mathrm{t}} \mathrm{G} 2 \mathrm{~A}$ mutant were established. The line with the highest expression level of $\mathrm{G} \alpha_{\mathrm{t}} \mathrm{G} 2 \mathrm{~A}$ was selected by immunoblot analysis with anti-EE antibody and used for breeding with $\mathrm{G} \alpha_{\mathrm{t}}$ knock-out mice (Calvert et al., 2000) to move the transgene into the hemizygous $\left(\mathrm{G}{\alpha_{\mathrm{t}}}^{+/-}\right)$and knock-out $\left(\mathrm{G}{\alpha_{\mathrm{t}}}^{-/-}\right)$backgrounds. Based on the immunoblot analysis of mouse retinal homogenates with anti$\operatorname{rod} \mathrm{G} \alpha_{\mathrm{t}}$ antibody, the total expression level of transducin- $\alpha$ $\left(\mathrm{G} \alpha_{\mathrm{t}} \mathrm{G} 2 \mathrm{~A}+\right.$ native $\left.\mathrm{G} \alpha_{\mathrm{t}}\right)$ in $\mathrm{G} \alpha_{\mathrm{t}} \mathrm{G} 2 \mathrm{~A} / \mathrm{G} \alpha_{\mathrm{t}}{ }^{+/-}$mice was similar to the $\mathrm{G} \alpha_{\mathrm{t}}$ level in wild-type $\left(\mathrm{G} \alpha_{\mathrm{t}}{ }^{+/+}\right)$mice (Fig. $\left.1 B\right)$. The level of $\mathrm{G} \alpha_{\mathrm{t}} \mathrm{G} 2 \mathrm{~A}$ in the $\mathrm{G} \alpha_{\mathrm{t}}$ knock-out background was $\sim 30 \%$ of the wild-type level (Fig. $1 B$ ). The blot analysis with EE antibody indicated that expression of $\mathrm{G} \alpha_{\mathrm{t}} \mathrm{G} 2 \mathrm{~A}$ in the $\mathrm{G} \alpha_{\mathrm{t}}{ }^{-1-}$ background was $\sim 1.5$-fold higher than in the $\mathrm{G}_{\mathrm{t}}{ }^{+/-}$background (Fig. $1 B, C)$, suggesting that $\mathrm{G} \alpha_{\mathrm{t}} \mathrm{G} 2 \mathrm{~A} / \mathrm{G} \alpha_{\mathrm{t}}{ }^{+/-}$mice express $\sim 20 \%$ $\mathrm{G} \alpha_{\mathrm{t}} \mathrm{G} 2 \mathrm{~A}$ and $80 \%$ native $\mathrm{G} \alpha_{\mathrm{t}}$. Control immunoblot tests demonstrated that the levels of $\mathrm{G} \beta_{1}$ and several major phototransduction components such as rhodopsin, $\operatorname{PDE} 6 \alpha \beta$, arrestin-1, and RGS9-1 were essentially unchanged in $\mathrm{G} \alpha_{\mathrm{t}} \mathrm{G} 2 \mathrm{~A} / \mathrm{G} \alpha_{\mathrm{t}}{ }^{-/-}$mice (Fig. 1D,E). Also, G $\alpha_{\mathrm{t}} \mathrm{G} 2 \mathrm{~A} / \mathrm{G} \alpha_{\mathrm{t}}{ }^{+-}$and $\mathrm{G} \alpha_{\mathrm{t}} \mathrm{G} 2 \mathrm{~A} / \mathrm{G} \alpha_{\mathrm{t}}{ }^{-1-}$ mice showed normal gross morphology of the retina with no apparent signs of retinal degeneration (data not shown).

In dark adapted rods, native transducin localizes to the OS. We examined subcellular localization of $\mathrm{G} \alpha_{\mathrm{t}} \mathrm{G} 2 \mathrm{~A}$ in transgenic 


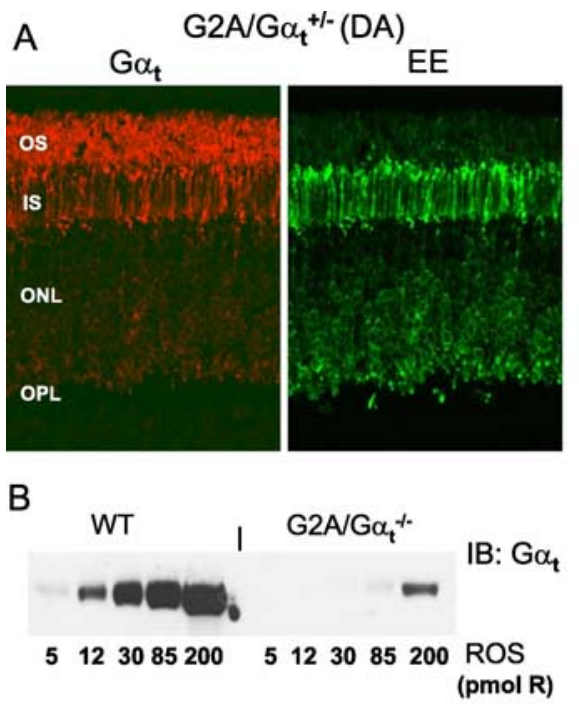

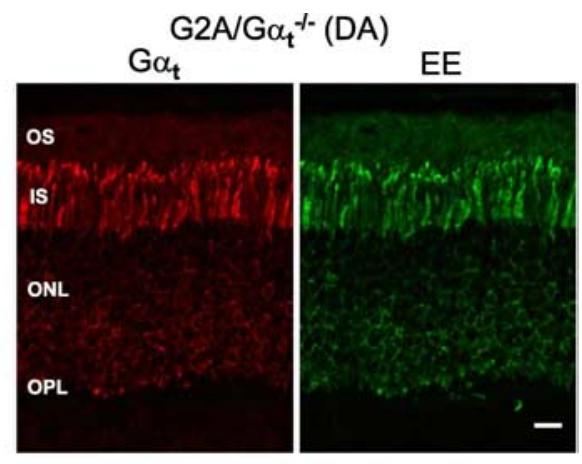

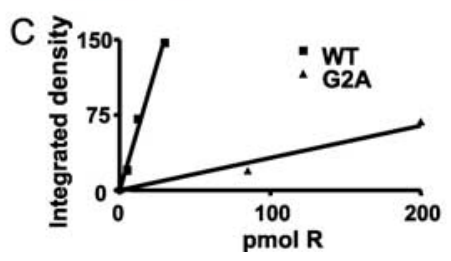

Figure 2. $\boldsymbol{A}$, Localization of total $\mathrm{G} \alpha_{\mathrm{t}}$ and mutant $\mathrm{G} \alpha_{\mathrm{t}} \mathrm{G} 2 \mathrm{~A}$ in dark-adapted (DA) mouse retinas. $\mathrm{G} \alpha_{\mathrm{t}} \mathrm{G} 2 \mathrm{~A} / \mathrm{G} \alpha_{\mathrm{t}}{ }^{+/-}$and $\mathrm{G} \alpha_{\mathrm{t}} \mathrm{G} 2 \mathrm{~A} / \mathrm{G} \alpha_{\mathrm{t}}{ }^{-1-}$ retina sections were stained with rabbit anti-rod $\mathrm{G} \alpha_{\mathrm{t}}$ antibody K-20 or a monoclonal anti-EE antibody and visualized with goat anti-rabbit AlexaFluor 555 and goat anti-mouse AlexaFluor 488 secondary antibodies using a Zeiss LSM 510 confocal microscope. Scale bar, $20 \mu \mathrm{m}$. IS, Inner segment; ONL, outer nuclear layer; OPL, outer plexiform layer. $\boldsymbol{B}$, Representative immunoblot (IB) analysis of relative levels of $\mathrm{G} \alpha_{\mathrm{t}} \mathrm{G} 2 \mathrm{~A}$ in $\mathrm{G} \alpha_{\mathrm{t}} \mathrm{G} 2 \mathrm{~A} / \mathrm{G} \alpha_{\mathrm{t}}{ }^{-1-}$ ROS and native $\mathrm{G} \alpha_{\mathrm{t}}$ in WT ROS. C, Quantification of the relative protein levels from the immunoblot in $\boldsymbol{B}$. The relative level of $\mathrm{G} \alpha_{\mathrm{t}}$ in WT ROS is $\sim 17$-fold higher than the level of $\mathrm{G} \alpha_{\mathrm{t}} \mathrm{G} 2 \mathrm{~A}$ in transgenic ROSs (calculated as the ratio of the linear fit slopes). The average ratio of the slopes in three similar experiments is $18 \pm 2$ (mean $\pm \mathrm{SE})$.

rods by immunofluorescence confocal microscopy of mouse retinal sections using anti-rod $\mathrm{G} \alpha_{\mathrm{t}}$ and anti-EE antibodies. In contrast to the native $\mathrm{G} \alpha_{\mathrm{t}}, \mathrm{G} \alpha_{\mathrm{t}} \mathrm{G} 2 \mathrm{~A}$ displayed extensive mislocalization to the inner compartments of rod photoreceptor cells (Fig. $2 A)$. Only a very weak EE signal was seen in the OS of $\mathrm{G} \alpha_{\mathrm{t}} \mathrm{G} 2 \mathrm{~A} /$ $\mathrm{G} \alpha_{\mathrm{t}}{ }^{+/-}$and $\mathrm{G} \alpha_{\mathrm{t}} \mathrm{G} 2 \mathrm{~A} / \mathrm{G} \alpha_{\mathrm{t}}{ }^{-1-}$ mice (Fig. 2A). ROS membranes were isolated from dark-adapted $\mathrm{G} \alpha_{\mathrm{t}} \mathrm{G} 2 \mathrm{~A} / \mathrm{G} \alpha_{\mathrm{t}}{ }^{-1-}$ and control $\mathrm{G} \alpha_{\mathrm{t}}{ }^{+/+}$mice to determine the fraction of the mutant that correctly localized to the OS. The ROS immunoblot analysis revealed that the level of $\mathrm{G} \alpha_{\mathrm{t}} \mathrm{G} 2 \mathrm{~A}$ in the OS is $\sim 5-6 \%$ of the $\mathrm{G} \alpha_{\mathrm{t}}$ level in control mice (Fig. $2 B, C$ ). Thus, $\mathrm{G} \alpha_{\mathrm{t}} \mathrm{G} 2 \mathrm{~A} / \mathrm{G} \alpha_{\mathrm{t}}{ }^{-1-}$ mice express $\mathrm{G} \alpha_{\mathrm{t}} \mathrm{G} 2 \mathrm{~A}$ at $\sim 30 \%$ of $\mathrm{G} \alpha_{\mathrm{t}}$ in wild-type mice, but only $15-20 \%$ of the mutant $\mathrm{G} \alpha_{\mathrm{t}}$ is able to reach the OS. This result is in agreement with the immunofluorescence staining of $\mathrm{G} \alpha_{\mathrm{t}} \mathrm{G} 2 \mathrm{~A}$ in the $\mathrm{G} \alpha_{\mathrm{t}} \mathrm{G} 2 \mathrm{~A} / \mathrm{G} \alpha_{\mathrm{t}}{ }^{-1-}$ retinal sections (Fig. $2 A$ ).

\section{Biochemical analysis of $\mathrm{G} \alpha_{\mathbf{t}} \mathrm{G} 2 \mathrm{~A}$}

The key signaling properties of $\mathrm{G} \alpha_{\mathrm{t}} \mathrm{G} 2 \mathrm{~A}$ such as its interaction with $\mathrm{G} \beta_{1} \gamma_{1}, \mathrm{R}^{*}$-dependent binding of GTP $\gamma \mathrm{S}$, GTPase activity, and the ability to activate PDE6 were examined using preparations of ROS membranes isolated from $\mathrm{G} \alpha_{\mathrm{t}} \mathrm{G} 2 \mathrm{~A} / \mathrm{G} \alpha_{\mathrm{t}}{ }^{-/-}$and control wild-type $\left(\mathrm{G} \alpha_{\mathrm{t}}{ }^{+/+}\right)$mice. To assay the ability of $\mathrm{G} \alpha_{\mathrm{t}} \mathrm{G} 2 \mathrm{~A}$ to bind $G \beta_{1} \gamma_{1}$, we measured the extent of pertussis toxininduced ADP ribosylation of $\mathrm{G} \alpha_{\mathrm{t}}$ at Cys347 (van Dop et al., 1984; West et al., 1985; Watkins et al., 1985). Holotransducin, $\mathrm{G} \alpha_{\mathrm{t}} \beta_{1} \gamma_{1}$, is a much-preferred substrate in this reaction compared with $\mathrm{G} \alpha_{\mathrm{t}}$ alone (Watkins et al., 1985). The extent of ADP ribosylation of $\mathrm{G} \alpha_{\mathrm{t}}$ in wild-type ROS and $\mathrm{G} \alpha_{\mathrm{t}} \mathrm{G} 2 \mathrm{~A}$ in transgenic ROS was similar, and both were inhibited comparably by the addition of $\mathrm{AlF}_{4}^{-}$ (Fig. $3 A$ ). $\mathrm{AlF}_{4}^{-}$ions activate GDP-bound $\mathrm{G} \alpha$ subunits by mimicking the $\gamma$-phosphate of GTP and causing dissociation of $\mathrm{G} \beta_{1} \gamma_{1}$. Thus, $\mathrm{G} \alpha_{\mathrm{t}} \mathrm{G} 2 \mathrm{~A}$ is capable of binding $\mathrm{G} \beta_{1} \gamma_{1}$ and is present in ROS of $\mathrm{G} \alpha_{\mathrm{t}} \mathrm{G} 2 \mathrm{~A} / \mathrm{G} \alpha_{\mathrm{t}}{ }^{-1-}$ mice as a heterotrimeric protein $\mathrm{G} \alpha_{\mathrm{t}} \mathrm{G} 2 \mathrm{~A} \beta_{1} \gamma_{1}$. The binding of wild-type $\mathrm{G} \alpha_{\mathrm{t}} \beta_{1} \gamma_{1}$ to $\mathrm{R}^{*}$ inhibited pertussis toxin-catalyzed ADP ribosylation of $\mathrm{G} \alpha_{\mathrm{t}}$, apparently by

masking the Cys residue (van Dop et al., 1984; Watkins et al., 1985; West et al., 1985). Likewise, ADP ribosylation of $\mathrm{G} \alpha_{\mathrm{t}} \mathrm{G} 2 \mathrm{~A} \beta_{1} \gamma_{1}$ was inhibited by light, suggesting specific binding of the mutant transducin to $\mathrm{R}^{*}$ (Fig. $3 A$ ).

The overall ability of $\alpha_{\mathrm{t}} \mathrm{G} 2 \mathrm{~A} \beta_{1} \gamma_{1}$ to be activated by $\mathrm{R}^{\star}$ was determined by lightdependent binding of GTP $\gamma S$ to ROS membranes from $\mathrm{G} \alpha_{\mathrm{t}} \mathrm{G} 2 \mathrm{~A} / \mathrm{G} \alpha_{\mathrm{t}}{ }^{-1-}$ mice. The level of light-dependent binding of $\left[{ }^{35} \mathrm{~S}\right] \mathrm{GTP} \gamma \mathrm{S}$ to $\mathrm{G} \alpha_{\mathrm{t}} \mathrm{G} 2 \mathrm{~A} / \mathrm{G} \alpha_{\mathrm{t}}{ }^{-/-}$ROS was $\sim 16$-fold lower than ( $6 \%$ of) that of wildtype ROS (Fig. 3B). The decrease in $\left[{ }^{35} \mathrm{~S}\right] \mathrm{GTP} \gamma \mathrm{S}$ binding to $\mathrm{G} \alpha_{\mathrm{t}} \mathrm{G} 2 \mathrm{~A}$ ROS is very similar to the reduction in the expression level of the mutant $\mathrm{G} \alpha_{\mathrm{t}}$ in the ROS fraction (18-fold) (Fig. $2 B$ ), indicating that the entire pool of $\mathrm{G} \alpha_{\mathrm{t}} \mathrm{G} 2 \mathrm{~A} \beta_{1} \gamma_{1}$ can be activated by $\mathrm{R}^{\star}$ in transgenic rods.

The GTPase activities of $\mathrm{G} \alpha_{\mathrm{t}} \mathrm{G} 2 \mathrm{~A}$ and native $\mathrm{G} \alpha_{\mathrm{t}}$ in $\mathrm{G} \alpha_{\mathrm{t}} \mathrm{G} 2 \mathrm{~A} / \mathrm{G} \alpha_{\mathrm{t}}{ }^{-/-}$and wildtype ROS membranes were measured under single turnover conditions $([\mathrm{GTP}]<$ $\left.\left[G_{t}\right]\right)$. A low substrate concentration (20 nM $\left.\left[\gamma_{-}{ }^{32} \mathrm{P}\right] \mathrm{GTP}\right)$ was used to ensure that the single turnover conditions held for the transgenic ROS with low levels of $\mathrm{G} \alpha_{\mathrm{t}} \mathrm{G} 2 \mathrm{~A}$. The rates of 0.15 and $0.09 \mathrm{~s}^{-1}$ for control and $\mathrm{G} \alpha_{\mathrm{t}} \mathrm{G} 2 \mathrm{~A} / \mathrm{G} \alpha_{\mathrm{t}}{ }^{-/-}$ ROS preparations, respectively, were determined from the singleexponential fits to the data (Fig. 3C). Hence, the G2A mutation caused an $\sim 1.7$-fold decrease in the rate of GTP hydrolysis by $\mathrm{G} \alpha_{\mathrm{t}}$.

The ability of $\mathrm{G} \alpha_{\mathrm{t}} \mathrm{G} 2 \mathrm{~A}$ to activate its effector, PDE6, was determined by measuring the rate of cGMP hydrolysis induced by the addition of GTP $\gamma \mathrm{S}$. The presence of GTP $\gamma \mathrm{S}$ caused marked stimulation of cGMP hydrolysis in control ROS but had an approximately sevenfold smaller effect in $\mathrm{G} \alpha_{\mathrm{t}} \mathrm{G} 2 \mathrm{~A} / \mathrm{G} \alpha_{\mathrm{t}}{ }^{-1-}$ ROS (Fig. 3D). As a control, ROS preparations were also treated with trypsin, which cleaves the inhibitory $\mathrm{P} \gamma$ subunit and produces full activation of the PDE6 present in the assay. The addition of trypsin resulted in equivalent enzyme activity in control and transgenic ROS preparations (Fig. 3D), indicating that the lower GTP $\gamma S$-induced PDE6 activation in $\mathrm{G} \alpha_{\mathrm{t}} \mathrm{G} 2 \mathrm{~A} / \mathrm{G} \alpha_{\mathrm{t}}{ }^{-/-}$ROS was not attributable to a reduction in PDE6 levels. Given the $\sim 18$ fold reduction in $\mathrm{G} \alpha_{\mathrm{t}} \mathrm{G} 2 \mathrm{~A}$ expression in the transgenic rods, the sevenfold reduction in GTP $\gamma S$-induced PDE6 activation indicates that the mutant $\mathrm{G} \alpha_{\mathrm{t}}$ not only is competent to activate its effector, but seems to do so even more efficiently than wild-type $\mathrm{G} \alpha_{\mathrm{t}}$.

\section{Physiology of $\mathrm{G} \alpha_{\mathrm{t}} \mathrm{G} 2 \mathrm{~A}$ rods}

To assess the ability of nonacylated $\mathrm{G} \alpha_{\mathrm{t}}$ to mediate phototransduction in intact cells, suction electrodes were used to record the light-induced decrease in plasma membrane current mediated by the closure of cGMP-gated ion channels (for review, see Burns and Arshavsky, 2005). The amplitude and time course of the light response provides a quantitative measure of amplification and deactivation of the phototransduction cascade in the intact cell (for review, see Pugh and Lamb, 2000). G $\alpha_{\mathrm{t}} \mathrm{G} 2 \mathrm{~A} / \mathrm{G} \alpha_{\mathrm{t}}{ }^{-/-}$rods responded to brief flashes of light in a manner similar to that of wild-type rods (Fig. 4A), indicating that $\mathrm{G} \alpha_{\mathrm{t}} \mathrm{G} 2 \mathrm{~A}$ indeed becomes activated by rhodopsin and in turn can bind and activate 
PDE6, generating sufficient cGMP hydrolysis to close cGMP-gated channels on the plasma membrane. However, $\mathrm{G} \alpha_{\mathrm{t}} \mathrm{G} 2 \mathrm{~A} / \mathrm{G} \alpha_{\mathrm{t}}{ }^{-/-}$rods were less sensitive than those of wild-type mice; the flash strength needed to generate a halfmaximal response was sixfold brighter than that for wild-type rods (Fig. $4 B$, Table 1). This decrease in sensitivity was not associated with a change in the ability of $\mathrm{G} \alpha_{\mathrm{t}} \mathrm{G} 2 \mathrm{~A} / \mathrm{G} \alpha_{\mathrm{t}}{ }^{-1-}$ rods to capture incident photons, because the effective collecting area of $0.17 \pm 0.03 \mu \mathrm{m}^{2}(n=$ 11) calculated by variance-to-mean analysis (see Materials and Methods) was similar to that of $0.23 \pm 0.03 \mu \mathrm{m}^{2}$ $(n=9)$ measured for wild-type rods $(p=0.20)$. Thus, the reduced sensitivity of $\mathrm{G} \alpha_{\mathrm{t}} \mathrm{G} 2 \mathrm{~A} / \mathrm{G} \alpha_{\mathrm{t}}{ }^{-1-}$ rods was not caused by a decrease in photon capture, but rather reduced activation of $\mathrm{G} \alpha_{\mathrm{t}} \mathrm{G} 2 \mathrm{~A}$ by photoexcited rhodopsin and/or reduced activation of PDE6 by $\mathrm{G} \alpha_{\mathrm{t}} \mathrm{G} 2 \mathrm{~A}$. Consistent with this idea, the average response generated by a single photoexcited rhodopsin was smaller for $\mathrm{G} \alpha_{\mathrm{t}} \mathrm{G} 2 \mathrm{~A} / \mathrm{G} \alpha_{\mathrm{t}}{ }^{-/-}$ rods than wild-type rods (Fig. $5 A$, Table $1)$. The population average $\mathrm{G} \alpha_{\mathrm{t}} \mathrm{G} 2 \mathrm{~A}$ response deviated from that of the average wild-type response early on the rising phase of the response (Fig. $5 B, C$ ), reaching a twofold smaller peak slightly earlier. The early rising phase of the response time course, $r(t)$, is well described by the activation theory of Pugh and Lamb (Lamb and Pugh, 1992; Pugh and Lamb, 1993):

$$
\frac{r(t)}{r_{\max }}=1-\exp \left[-\frac{1}{2} A \phi\left(t-t_{\mathrm{eff}}\right)^{2}\right],
$$

where $r_{\max }$ is the saturating amplitude, $A$ is the amplification constant, Ö is the average number of photoexcited rhodopsins, and $t_{\text {eff }}$ is an effective delay, which we assumed to be $2 \mathrm{~ms}$. This equation was fitted to the population average single-photon responses $(\phi=1)$ to yield calculated $A$ values of $12.4 \mathrm{~s}^{-2}$ for wildtype and $4.10 \mathrm{~s}^{-2}$ for $\mathrm{G} \alpha_{\mathrm{t}} \mathrm{G} 2 \mathrm{~A}$ rods (Fig. $5 C$ ).

The light responses of $\mathrm{G} \alpha_{\mathrm{t}} \mathrm{G} 2 \mathrm{~A} / \mathrm{G} \alpha_{\mathrm{t}}{ }^{-1-}$ rods also showed abnormal recovery kinetics. Whereas the dim flash responses of wild-type rods showed a final recovery time course approximated by a single exponential function with a $240 \mathrm{~ms}$ time constant, dim flash responses of $\mathrm{G} \alpha_{\mathrm{t}} \mathrm{G} 2 \mathrm{~A} / \mathrm{G} \alpha_{\mathrm{t}}{ }^{-1-}$ rods recovered more slowly, with a time constant of $\sim 500 \mathrm{~ms}$. Likewise, for bright flash responses, the dominant time constant of recovery (Nikonov et al., 1998) was approximately threefold longer for $\mathrm{G} \alpha_{\mathrm{t}} \mathrm{G} 2 \mathrm{~A}$ rods than for wild-type rods (Table 1 ). The slower recovery in the transgenic rods is consistent with the prolonged lifetime of activated $\mathrm{G} \alpha_{\mathrm{t}} \mathrm{G} 2 \mathrm{~A}$ resulting from impaired GTPase activity (Fig. $3 C$ ).

\section{Discussion}

This work represents the first investigation of the functional significance of $\mathrm{N}$-terminal acylation in transducin function. The immunofluorescence analysis of retinal sections from transgenic
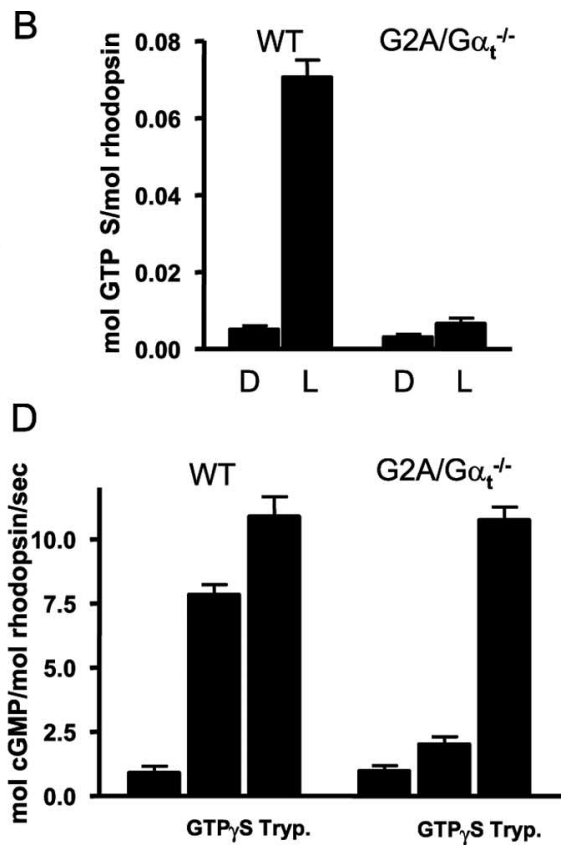

Figure 3. A, Pertussis toxin-catalyzed ADP ribosylation of $\mathrm{G} \alpha_{\mathrm{t}}$ and $\mathrm{G} \alpha_{\mathrm{t}} \mathrm{G} 2 \mathrm{~A}$. Dark-isolated (D) or bleached (L) WT ROS $(0.6 \mu \mathrm{M}$ 列 ${ }^{-1}$ (mean $\pm \mathrm{SE} ; n=3$ ). D. PDE6 activation in ROS membranes. GMP hydrolysis was measured in suspensions of bleached ROS membranes $(3 \mu \mathrm{MR})$ in the absence or presence of $10 \mu \mathrm{M}$ GTP $\gamma S$ using a 30 s incubation with $4 \mathrm{~mm}\left[{ }^{3} \mathrm{H}\right] \mathrm{CGMP}$. Trypsin (Tryp.)treated ROS were prepared as described in Materials and Methods. Error bars indicate SE $(n=3)$.

mice expressing the $\mathrm{N}$-acylation-deficient $\mathrm{G} \alpha_{\mathrm{t}}$ revealed a clear defect in $\mathrm{G} \alpha_{\mathrm{t}} \mathrm{G} 2 \mathrm{~A}$ localization. The major fraction of $\mathrm{G} \alpha_{\mathrm{t}} \mathrm{G} 2 \mathrm{~A}$ in the $\mathrm{G} \alpha_{\mathrm{t}}$ knock-out background was found in the inner compartments of transgenic rods instead of the OS. The marked mislocalization of $\mathrm{G} \alpha_{\mathrm{t}} \mathrm{G} 2 \mathrm{~A}$ did not result from the disruption of the $\mathrm{G} \alpha_{\mathrm{t}}-\mathrm{G} \beta_{1} \gamma_{1}$ interaction (Fig. 3A). Therefore, our results show for the first time the critical role of $\mathrm{G} \alpha_{\mathrm{t}} \mathrm{N}$-acylation in transducin localization. Native holo-transducin carries two lipid anchors, $\mathrm{N}$-acyl on $\mathrm{G} \alpha_{\mathrm{t}}$ and C-terminal farnesyl on $\mathrm{G} \gamma_{1}$, which appear to be necessary and sufficient for trafficking $\mathrm{G} \alpha_{t} \beta_{1} \gamma_{1}$ to the OS in the dark-adapted retinas. Interestingly, $G \beta_{1} \gamma_{1}$ is relatively evenly distributed between the OS and the rod inner compartments in $\mathrm{G} \alpha_{\mathrm{t}}$ knock-out mice (Zhang et al., 2003). Hence, the lipophilic nature of the transducin molecules determined by the lipid modifications decreases in the same order as the ability to correctly localize to the OS: $\mathrm{G} \alpha_{\mathrm{t}} \beta_{1} \gamma_{1}>\mathrm{G} \beta_{1} \gamma_{1}>\mathrm{G} \alpha_{\mathrm{t}} \mathrm{G} 2 \mathrm{~A} \beta_{1} \gamma_{1}$. We surmise from this analysis that the lipid anchors on $\mathrm{G} \alpha_{\mathrm{t}} \beta_{1} \gamma_{1}$, particularly the $\mathrm{N}$-terminal acylation of $\mathrm{G} \alpha$, represent key determinants for transducin compartmentalization to the OS.

The biochemical analysis of $\mathrm{G} \alpha_{\mathrm{t}} \mathrm{G} 2 \mathrm{~A}$ in transgenic ROS indicated that the lack of $\mathrm{N}$-acylation of $\mathrm{G} \alpha_{\mathrm{t}}$ does not block the activation of mutant transducin by $\mathrm{R}^{*}$, nor the GTP $\gamma \mathrm{S}$-induced activation of PDE6 by G $\alpha_{\mathrm{t}} \mathrm{G} 2 \mathrm{~A}$, although the extent of each of these reactions was severely reduced. This reduction is likely attributable to the $\sim 18$-fold lower than normal concentration of $\mathrm{G} \alpha_{\mathrm{t}} \mathrm{G} 2 \mathrm{~A}$. In light of the greatly reduced levels of activatable 


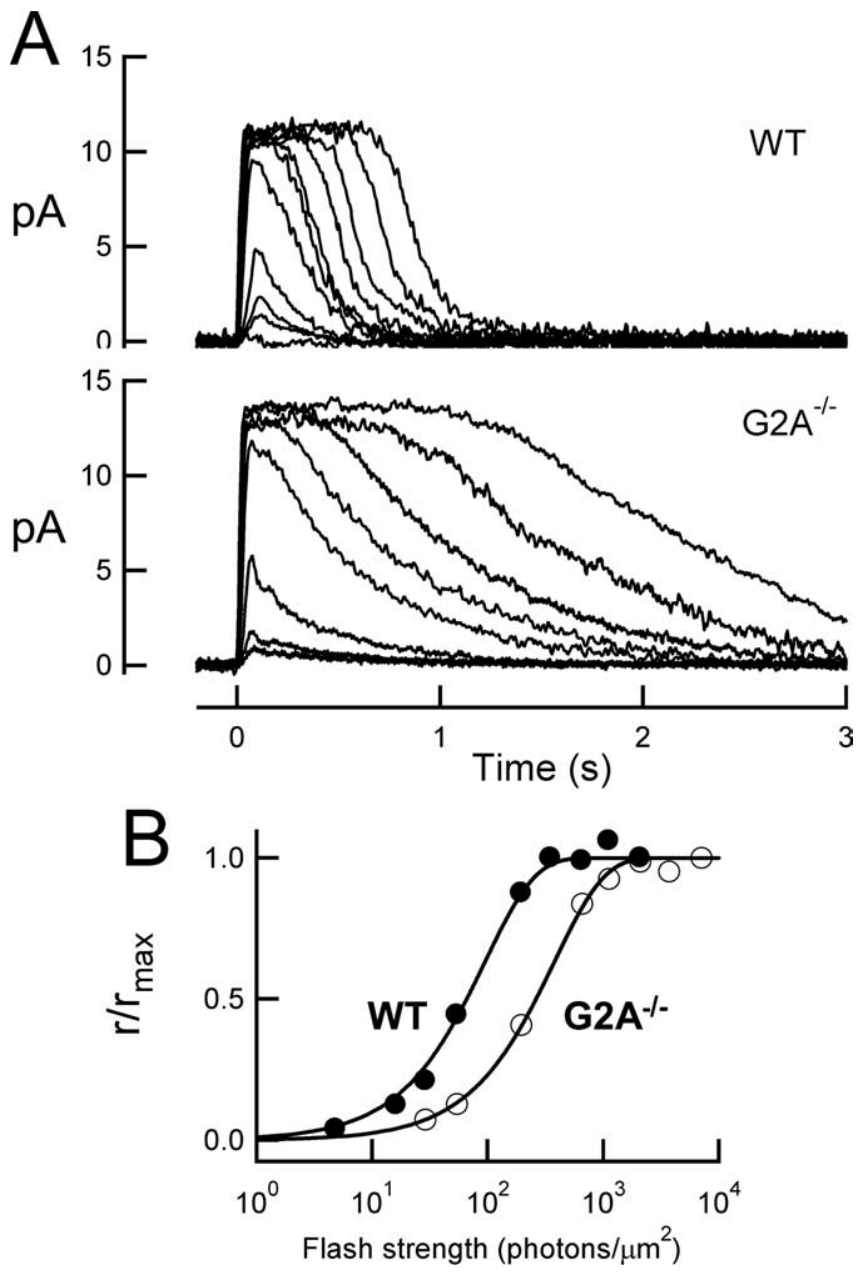

Figure 4. $G \alpha_{\mathrm{t}} \mathrm{G} 2 \mathrm{~A}$ rods are less sensitive than normal. $\boldsymbol{A}$, Representative families of responses from a wild-type rod (top) and a transgenic $\mathrm{G} \alpha_{\mathrm{t}} \mathrm{G} 2 \mathrm{~A} / \mathrm{G} \alpha_{\mathrm{t}}{ }^{-1-}$ rod. Flashes (10 ms, 500 $\mathrm{nm}$ ) were delivered at $t=0$. $\boldsymbol{B}$, The flash strengths needed to generate the same relative response amplitudes were higher for the $G \alpha_{\mathrm{t}} \mathrm{G} \mathrm{GA} / \mathrm{G} \alpha_{\mathrm{t}}{ }^{-1-}$ rod. Data are from the same cells as in $\boldsymbol{A}$. Curves are saturating exponential fits.

$\mathrm{G} \alpha_{\mathrm{t}} \mathrm{G} 2 \mathrm{~A}$, it is remarkable that the sensitivity of $\mathrm{G} \alpha_{\mathrm{t}} \mathrm{G} 2 \mathrm{~A} / \mathrm{G} \alpha_{\mathrm{t}}{ }^{-/-}$ rods was not correspondingly reduced. Instead, this 18 -fold reduction in heterotrimer levels was associated with an amplification constant that was reduced only by a factor of three (Fig. 5).

From a theoretical analysis of the phototransduction cascade, the amplification constant is proportional, among other things, to the rate of $G_{t}$ activation per $R^{\star}\left(\nu_{R G}\right)$, the coupling efficiency $\left(\mathrm{c}_{\mathrm{GP}}\right.$; defined as the ratio of activated $\mathrm{G} \alpha_{\mathrm{t}}$ to activated PDE6 subunits), and $\beta_{\text {sub }}$, the rate constant of cGMP hydrolysis by $\mathrm{G} \alpha_{\mathrm{t}}$-activated PDE subunit (Pugh and Lamb, 1993). Of these parameters, only $\nu_{\mathrm{RG}}$ is expected to be dependent on expression level, because it is thought to be limited by the rate of diffusional encounter between a single $R^{*}$ and transducin molecules on the disc membrane (Lamb and Pugh, 1992; Pugh and Lamb, 1993; Calvert et al., 2001). For the mammalian rod at $37^{\circ} \mathrm{C}$, the diffusion limit on $\nu_{\mathrm{RG}}$ can be described by a simplified equation:

$$
\nu_{R G} \leq 1.7\left(D_{R}+D_{G}\right) C_{G},
$$

where $D_{\mathrm{R}}$ and $D_{\mathrm{G}}$ are the lateral diffusion coefficients of $\mathrm{R}^{\star}$ and transducin on the disc membrane, and $C_{\mathrm{G}}$ is the concentration (surface density) of transducin on the membrane (Lamb and Pugh, 1992; Pugh and Lamb, 1993). Thus, an $\sim 18$ -
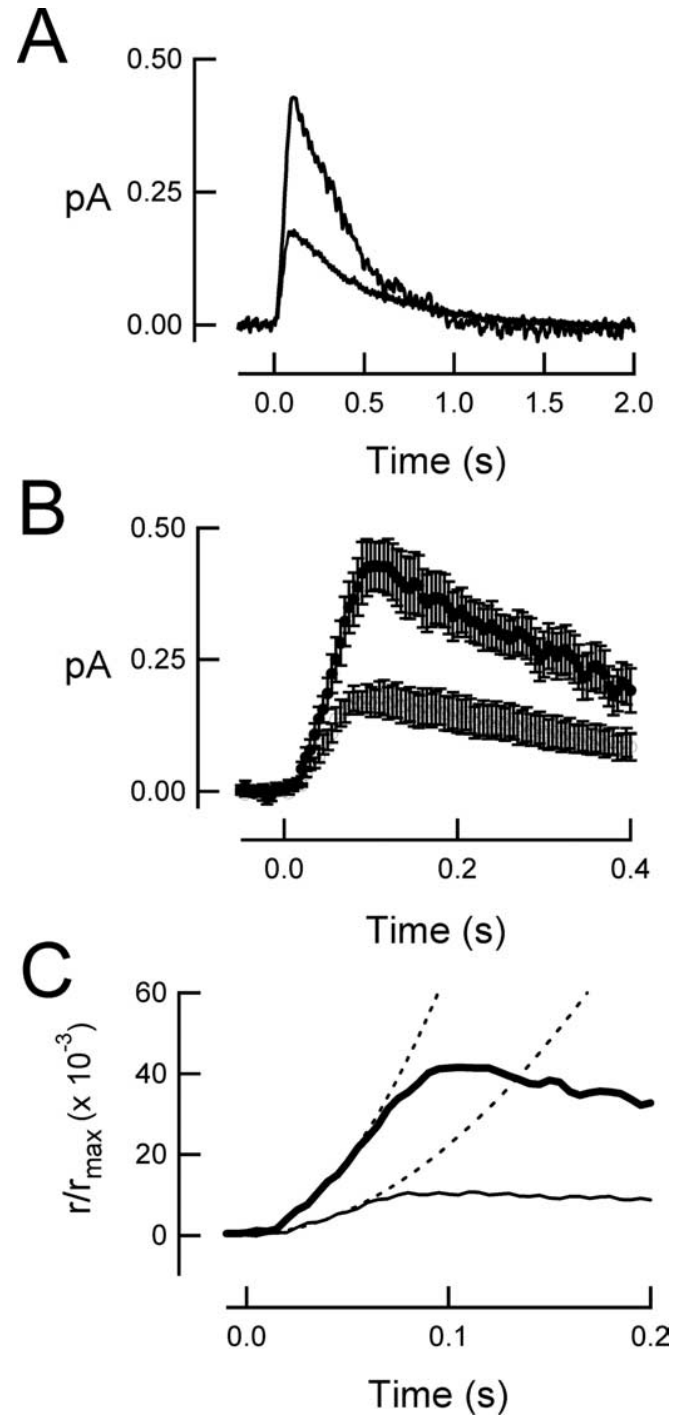

Figure 5. Population average single-photon responses reveal decrease in amplification in $\mathrm{G} \alpha_{\mathrm{t}} \mathrm{G} 2 \mathrm{~A} / \mathrm{G} \alpha_{\mathrm{t}}{ }^{-1-}$ rods. A, Un-normalized average single-photon response from $11 \mathrm{G} \alpha_{\mathrm{t}} \mathrm{G} 2 \mathrm{~A} /$ $\mathrm{G} \alpha_{\mathrm{t}}{ }^{-1-}$ rods (bottom trace) and 10 wild-type rods (top trace). The average dark current for the wild-type rods was $10.3 \mathrm{pA}$, and that for the $G \alpha_{\mathrm{t}} \mathrm{G} 2 \mathrm{~A}$ rods was $16.6 \mathrm{pA}$. $\boldsymbol{B}$, Same responses as in $A$, on an expanded time scale. Error bars indicate SEM. C, Same responses as in $A$, on a further expanded time scale. The dotted curves are the best parabolic fits of Equation 23 of Pugh and Lamb (1993) (see Results, Physiology of $G \alpha_{t} G 2 A$ rods, Eq. 2), yielding amplification constants of $12.4 \mathrm{~s}^{-2}$ for the average wild-type response and $4.1 \mathrm{~s}^{-2}$ for the average $\mathrm{G} \alpha_{\mathrm{t}} \mathrm{G} 2 \mathrm{~A} / \mathrm{G} \alpha_{\mathrm{t}}{ }^{-\prime-}$ response.

fold reduction of transducin concentration in the transgenic OS might be expected to cause an equivalent reduction in the amplification constant (and the rates of $G_{t}$ and PDE6 activation per $\mathrm{R}^{\star}$ ). Of course, if the $\mathrm{G} 2 \mathrm{~A}$ mutation also reduces $\mathrm{c}_{\mathrm{GP}}$ and/or $\beta_{\text {sub }}$ (which together define the ability of a given $\mathrm{G} \alpha_{\mathrm{t}} \mathrm{G} 2 \mathrm{~A}$ to activate a PDE6 subunit), then $A$ would be expected to be even lower still.

How then do we explain the only threefold reduction in the amplification constant? One possibility is that the lack of $\mathrm{N}$-acylation increases the lateral diffusion of $\mathrm{G}_{\mathrm{t}}$, thereby increasing its encounter rate with $\mathrm{R}^{\star}$ and the $\nu_{\mathrm{RG}}$ rate. According to Equation 3 and taking the estimates $D_{\mathrm{R}} \sim 1.5$ and $D_{\mathrm{G}} \sim 1.8$ $\mu \mathrm{m}^{2} \cdot \mathrm{s}^{-1}$ at $37^{\circ} \mathrm{C}$ (Pugh and Lamb, 1993), an 18 -fold reduction in $C_{\mathrm{G}}$ accompanied by a threefold reduction in $A$ implies a coincident tenfold increase in $D_{\mathrm{G}}$. On the other hand, 
Table 1. Characteristics of wild-type and $\mathrm{N}$-acylation-deficient $\mathrm{G} \alpha_{\mathrm{t}}$ rods

\begin{tabular}{|c|c|c|c|c|c|c|c|}
\hline & Dark current $(p A)$ & $I_{0}^{a}\left(\right.$ photons $\left./ \mu \mathrm{m}^{2}\right)$ & $\begin{array}{l}\text { Integration } \\
\text { time (ms) }\end{array}$ & $\begin{array}{l}\text { Dim flash } \tau_{\text {rec }} \\
\text { (ms) }\end{array}$ & $\begin{array}{l}\text { Time to peak } \\
\text { (ms) }\end{array}$ & $\begin{array}{l}\text { Elementary am- } \\
\text { plitude (pA) }\end{array}$ & $\begin{array}{l}\text { Bright flash } \\
\tau_{\mathrm{D}}^{b}(\mathrm{~ms})\end{array}$ \\
\hline $\mathrm{G} 2 \mathrm{~A}^{-1-}$ & $13.9 \pm 0.7(33)$ & $341.1 \pm 24.2(28)$ & $407 \pm 30(27)$ & $487 \pm 32(26)$ & $102 \pm 6(30)$ & $0.23 \pm 0.03(11)$ & $672 \pm 98(6)$ \\
\hline $\mathrm{G} 2 \mathrm{~A}^{+/-}$ & $10.4 \pm 1.1(11)$ & $65.6 \pm 16.3(7)$ & $259 \pm 32(9)$ & $245 \pm 27(10)$ & $116 \pm 9(10)$ & $0.58 \pm 0.15(5)$ & $184 \pm 14(6)$ \\
\hline Wild type & $10.8 \pm 0.9(15)$ & $53.0 \pm 3.9(14)$ & $324 \pm 30(13)$ & $239 \pm 19(13)$ & $116 \pm 7(14)$ & $0.51 \pm 0.07(10)$ & $224+11(10)$ \\
\hline
\end{tabular}

Numbers in parentheses represent $n$.

${ }^{a}$ Flash strength that elicited a half-maximal response.

${ }^{b}$ Dominant time constant for recovery of saturating flash responses.

G $\alpha_{\mathrm{t}} \mathrm{G} 2 \mathrm{~A}$ may actually activate PDE6 more effectively than normal $\mathrm{G} \alpha_{\mathrm{t}}$ (i.e., couple to PDE6 with higher $\mathrm{c}_{\mathrm{GP}}$ and/or induce higher $\left.\beta_{\text {sub }}\right)$. Support for this comes in part from the results of Figure $3 D$, which showed a sevenfold decrease in GTP $\gamma$ S-dependent PDE6 activity, compared with the 18-fold decrease in $\mathrm{G} \alpha_{\mathrm{t}} \mathrm{G} 2 \mathrm{~A}$ expression. Still, the PDE6 activation results in vitro do not necessarily indicate greater ability of $\mathrm{G} \alpha_{\mathrm{t}} \mathrm{G} 2 \mathrm{~A}$ to activate PDE6 in intact rods, because the assay was conducted in diluted suspensions of ROS membranes. Finally, it may be that the amplification constant does not scale linearly with transducin expression. Although previous studies have demonstrated a clear correlation between $A$ and outer segment $G_{t}$ levels (Sokolov et al., 2002), the linearity of this relationship has not been explicitly studied. Because the surface density of transducin is comparable with the Michaelis constant for rhodopsin-transducin binding at $34^{\circ} \mathrm{C}$ (Heck and Hofmann, 2001), the rate of activation by transducin might be less than linearly dependent on transducin expression.

Another clear effect of the G2A mutation is the slower than normal recovery of flash responses of transgenic rods. The time constants of recovery of dim and bright flash responses of $\mathrm{G} \alpha_{\mathrm{t}} \mathrm{G} 2 \mathrm{~A} / \mathrm{G} \alpha_{\mathrm{t}}{ }^{-1-}$ rods are approximately two and three times slower than normal, respectively (Table 1 ), consistent with the reduced GTPase activity of $\mathrm{G} \alpha_{\mathrm{t}} \mathrm{G} 2 \mathrm{~A}$ in ROS membranes (Fig. $3 C)$. In mouse rods, the time constant of dim flash response recovery and the dominant time constant for bright flash response recovery are both sensitive to the expression levels of the RGS9-1/G $\beta_{5}$ complex (Krispel et al., 2006). The GAP activity of RGS9-1/G $\beta_{5}$ is greatly accelerated by formation of the membrane-bound complex with the membrane anchor, R9AP (Lishko et al., 2002; Hu et al., 2003). We propose that the $\mathrm{N}$-acylation of $\mathrm{G} \alpha_{\mathrm{t}}$ along with lipid modifications of PDE6 provides for tight tethering of the activated $\mathrm{G} \alpha_{\mathrm{t}} / \mathrm{PDE} 6$ complex to the membrane, which enables a more efficient deactivation of $\mathrm{G} \alpha$ by the GAP complex. Overall, this study demonstrates that in addition to the critical role in trafficking and subcellular localization, the $\mathrm{N}$-acylation of transducin is essential for the normal recovery of rod photoresponses.

\section{References}

Bourne HR (1997) How receptors talk to trimeric G proteins. Curr Opin Cell Biol 9:134-142.

Burns ME, Arshavsky VY (2005) Beyond counting photons: trials and trends in vertebrate visual transduction. Neuron 48:387-401.

Burns ME, Baylor DA (2001) Activation, deactivation, and adaptation in vertebrate photoreceptor cells. Annu Rev Neurosci 24:779-805.

Cabrera-Vera TM, Vanhauwe J, Thomas TO, Medkova M, Preininger A, Mazzoni MR, Hamm HE (2003) Insights into G protein structure, function, and regulation. Endocr Rev 24:765-781.

Calvert PD, Krasnoperova NV, Lyubarsky AL, Isayama T, Nicolo M, Kosaras B, Wong G, Gannon KS, Margolskee RF, Sidman RL, Pugh Jr EN, Makino CL, Lem J (2000) Phototransduction in transgenic mice after targeted deletion of the rod transducin $\alpha$-subunit. Proc Natl Acad Sci USA 97:13913-13918.

Calvert PD, Govardovskii VI, Krasnoperova N, Anderson RE, Lem J, Makino
CL (2001) Membrane protein diffusion sets the speed of rod phototransduction. Nature 411:90-94.

Catty P, Pfister C, Bruckert F, Deterre P (1992) The cGMP phosphodiesterase-transducin complex of retinal rods. Membrane binding and subunits interactions. J Biol Chem 267:19489-19493.

Chen CA, Manning DR (2001) Regulation of G proteins by covalent modification. Oncogene 20:1643-1652.

Clerc A, Bennett N (1992) Activated cGMP phosphodiesterase of retinal rods. A complex with transducin $\alpha$ subunit. J Biol Chem 267:6620-6627.

Escriba PV, Wedegaertner PB, Goni FM, Vogler O (2006) Lipid-protein interactions in GPCR-associated signaling. Biochim Biophys Acta 1768:836-852.

Heck M, Hofmann KP (2001) Maximal rate and nucleotide dependence of rhodopsin-catalyzed transducin activation: initial rate analysis based on a double displacement mechanism. J Biol Chem 276:10000-10009.

Higgins JB, Casey PJ (1996) The role of prenylation in G-protein assembly and function. Cell Signal 8:433-437.

Hu G, Zhang Z, Wensel TG (2003) Activation of RGS9-1GTPase acceleration by its membrane anchor, R9AP. J Biol Chem 278:14550-14554.

Kassai H, Aiba A, Nakao K, Nakamura K, Katsuki M, Xiong WH, Yau KW, Imai H, Shichida Y, Satomi Y, Takao T, Okano T, Fukada Y (2005) Farnesylation of retinal transducin underlies its translocation during light adaptation. Neuron 47:529-539.

Kerov V, Chen D, Moussaif M, Chen YJ, Chen CK, Artemyev NO (2005) Transducin activation state controls its light-dependent translocation in rod photoreceptors. J Biol Chem 280:41069-41076.

Krispel CM, Chen D, Melling N, Chen YJ, Martemyanov KA, Quillinan N, Arshavsky VY, Wensel TG, Chen CK, Burns ME (2006) RGS expression rate-limits recovery of rod photoresponses. Neuron 51:409-416.

Lamb TD, Pugh Jr EN (1992) A quantitative account of the activation steps involved in phototransduction in amphibian photoreceptors. J Physiol (Lond) 449:719-758.

Lem J, Applebury ML, Falk JD, Flannery JG, Simon MI (1991) Tissuespecific and developmental regulation of rod opsin chimeric genes in transgenic mice. Neuron 6:201-210.

Lishko PV, Martemyanov KA, Hopp JA, Arshavsky VY (2002) Specific binding of RGS9-G $\beta 5 \mathrm{~L}$ to protein anchor in photoreceptor membranes greatly enhances its catalytic activity. J Biol Chem 277:24376-24381.

Lobanova ES, Finkelstein S, Song H, Tsang SH, Chen CK, Sokolov M, Skiba NP, Arshavsky VY (2007) Transducin translocation in rods is triggered by saturation of the GTPase-activating complex. J Neurosci 27:1151-1160.

Moussaif M, Rubin WW, Kerov V, Reh R, Chen D, Lem J, Chen C-K, Hurley JB, Burns ME, Artemyev NO (2006) Phototransduction in a transgenic mouse model of Nougaret night blindness. J Neurosci 26:6863-6872.

Neubert TA, Hurley JB (1998) Functional heterogeneity of transducin $\alpha$ subunits. FEBS Lett 422:343-345.

Neubert TA, Johnson RS, Hurley JB, Walsh KA (1992) The rod transducin $\alpha$ subunit amino terminus is heterogeneously fatty acylated. J Biol Chem 267:18274-18277.

Nikonov S, Engheta N, Pugh Jr EN (1998) Kinetics of recovery of the darkadapted salamander rod photoresponse. J Gen Physiol 111:7-37.

Pierce KL, Premont RT, Lefkowitz RJ (2002) Seven-transmembrane receptors. Nat Rev Mol Cell Biol 3:639-650.

Pugh Jr EN, Lamb TD (1993) Amplification and kinetics of the activation steps in phototransduction. Biochim Biophys Acta 1141:111-1149.

Pugh Jr EN, Lamb TD (2000) Phototransduction in vertebrate rods and cones: molecular mechanisms of amplification, recovery and light adap- 
tation. In: Handbook of biological physics, Vol 3, Molecular mechanisms in visual transduction (Stavenga DG, de Grip WJ, Pugh EN, eds), pp 183-254. Atlanta, GA: Elsevier.

Raport CJ, Dere B, Hurley JB (1989) Characterization of the mouse rod transducin $\alpha$ subunit gene. J Biol Chem 264:7122-7128.

Sokolov M, Lyubarsky AL, Strissel KJ, Savchenko AB, Govardovskii VI, Pugh Jr EN, Arshavsky VY (2002) Massive light-driven translocation of transducin between the two major compartments of rod cells: a novel mechanism of light adaptation. Neuron 34:95-106.

Tsang SH, Burns ME, Calvert PD, Gouras P, Baylor DA, Goff SP, Arshavsky VY (1998) Role for the target enzyme in deactivation of photoreceptor G protein in vivo. Science 282:117-121.

van Dop C, Yamanaka G, Steinberg F, Sekura RD, Manclark CR, Stryer L, Bourne HR (1984) ADP-ribosylation of transducin by pertussis toxin blocks the light-stimulated hydrolysis of GTP and cGMP in retinal photoreceptors. J Biol Chem 259:23-26.

Watkins PA, Burns DL, Kanaho Y, Liu TY, Hewlett EL, Moss J (1985) ADPribosylation of transducin by pertussis toxin. J Biol Chem 260:13478-13482.

Wedegaertner PB, Wilson PT, Bourne HR (1995) Lipid modifications of trimeric $\mathrm{G}$ proteins. J Biol Chem 270:503-506.

West Jr RE, Moss J, Vaughan M, Liu T, Liu TY (1985) Pertussis toxincatalyzed ADP-ribosylation of transducin. Cysteine 347 is the ADP-ribose acceptor site. J Biol Chem 260:14428-14430.

Zhang H, Huang W, Zhang H, Zhu X, Craft CM, Baehr W, Chen C-K (2003) Light-dependent redistribution of visual arrestins and transducin subunits in mice with defective phototransduction. Mol Vis 9:231-237. 